\title{
Sexual dimorphism based on body proportions and ontogenetic changes in the Brazilian electric ray Narcine brasiliensis (von Olfers, 1831) (Chondrichthyes: Narcinidae)
}

\author{
FA Rolim, FP Caltabellotta, MM Rotundo \& T Vaske-Júnior
}

To cite this article: FA Rolim, FP Caltabellotta, MM Rotundo \& T Vaske-Júnior (2015) Sexual dimorphism based on body proportions and ontogenetic changes in the Brazilian electric ray Narcine brasiliensis (von Olfers, 1831) (Chondrichthyes: Narcinidae), African Journal of Marine Science, 37:2, 167-176, DOI: 10.2989/1814232X.2015.1032350

To link to this article: https://doi.org/10.2989/1814232X.2015.1032350

\section{Published online: 24 Jul 2015.}

Submit your article to this journal $\sqsubset$

\section{Џ Article views: 68}

\section{View Crossmark data ¿}




\title{
Sexual dimorphism based on body proportions and ontogenetic changes in the Brazilian electric ray Narcine brasiliensis (von Olfers, 1831) (Chondrichthyes: Narcinidae) $)^{\S}$
}

\author{
FA Rolim ${ }^{1 *}$, FP Caltabellotta², MM Rotundo ${ }^{3}$ and T Vaske-Júnior ${ }^{4}$ \\ 1 Fisheries Institute of São Paulo, Santos, Brazil; current address: Biosciences Institute, São Paulo State University - \\ UNESP, Rio Claro, São Paulo, Brazil \\ 2 Oceanography Department, University Center Monte Serrat - UNIMONTE, Santos, São Paulo, Brazil \\ ${ }^{3}$ Zoological Collection of University of Santa Cecilia - UNISANTA, Santos, São Paulo, Brazil \\ ${ }^{4}$ Elasmobranch Laboratory, São Paulo State University - UNESP, Coastal Campus, São Vicente, São Paulo, Brazil \\ *Corresponding author, e-mail: fernandarolim2@gmail.com
}

\begin{abstract}
Sexual dimorphism in the Brazilian electric ray Narcine brasiliensis from the south-western Atlantic coast was evaluated based on body proportions and ontogenetic changes. All regions of the body were found to have differences in body proportions between the sexes, except the spiracles. The nature of allometric and isometric relationships differed mainly in terms of the six largest body dimensions. Some of these differences can be supported by the species' life history. Principal components analysis (PCA) and analysis of similarities (ANOSIM) distinguished the adults' body proportions by sex. Similarity percentage analysis (SIMPER) selected six variables that best discriminated between the sexes with a cumulative difference up to $70 \%$ (tail width, disc width, length between snout and first dorsal fin, pelvic fin width, length between snout and the widest part of the disc, and disc length). It was possible to select seven stable dimensions, both ontogenetic and sexual, that are recommended for use in taxonomic studies. These dimensions were interspiracular distance, spiracle length and width, upper and lower tooth band width, pelvic fin length, and length of posterior lobe of the pelvic fin. It is important to consider the differences in body proportions within a species in order to properly characterise the population and estimate its most reliable parameters.
\end{abstract}

Keywords: Elasmobranchii, morphometry, relative growth, Torpediniformes

Introduction

Morphological variations resulting from ontogeny and sexual dimorphism of a species are useful tools in taxonomic studies on elasmobranch fishes (Castillo-Geniz et al. 2007), particularly for those that exhibit conservative body features, as stated for the North Pacific skate family Rajidae (Ishihara and Ishiyama 1985). Furthermore, such studies provide pivotal information on the life-history aspects (e.g. habitat use, intraspecific interactions and trophic ecology) of the individual species and at the population level. Nevertheless, such studies are scarce and this information is virtually unknown for most species. Studies involving morphological variation in batoids typically refer to the family Rajidae due to the recognised and remarkable morphological discrimination between adult males and females (e.g. Feduccia and Slaugher 1974; Braccini and Chiaramonte 2002; CastilloGeniz et al. 2007; Orlov and Smirnov 2011). For the sharks, the catshark genus Scyliorhinus (family Scyliorhinidae) has been the most frequently studied group (e.g. Brough 1937; Ellis and Shackley 1995; Litvinov 2003; Filiz and Taskavak 2006).

The numbfishes (Torpediniformes, Narcinidae) are represented by four genera, including the genus Narcine that consists of small- to moderate-sized (about $930 \mathrm{~mm}$ total length), coastal, benthic batoids that are widely distributed from tropical to temperate waters (McEachran and de Carvalho 2002; Last and Stevens 2009; VillavicencioGarayzar and Bizzarro 2009). In the western Atlantic, Narcine brasiliensis, once regarded as a wide-ranging species, has more recently been regarded as a complex of at least three species, as follows: $N$. brasiliensis found from south-eastern Brazil to Argentina; $N$. bancroftii from North Carolina, USA, to north-eastern Brazil (although the southernmost distribution limit is unclear); and Narcine sp. from Suriname to northern Brazil (de Carvalho 1999; McEachran and de Carvalho 2002). This led to the re-evaluation of the available information on the biological and functional morphology of $N$. bancroftii that was previously attributed to $N$. brasiliensis in the western North Atlantic (e.g. Mathewson et al. 1958; Villavicencio-Garayzar 1993; Dean and Motta 2004; Dean et al. 2005).

The Brazilian electric ray $N$. brasiliensis is distributed along the entire southern Brazilian continental shelf, in shallow waters that are usually $\leq 20 \mathrm{~m}$ deep, but it can be found at depths of up to $60 \mathrm{~m}$, over soft sand or mud substrata. Specimens are often caught incidentally by trawl

$\S$ This article is based on a paper presented at the 'Sharks International 2014' conference, held 2-6 June 2014, Durban, South Africa, and is part of a special issue 'Advances in Shark Research' edited by DA Ebert, C Huveneers and SFJ Dudley 
fisheries and discarded, since they do not have commercial value (Martins et al. 2009; Vianna and Vooren 2009). The few biological studies available have reported on the species' feeding habits, and have concluded that it preys upon small crustaceans and polychaetes (Goitein et al. 1998; Bornatowski et al. 2006). Other biological data and population parameters are virtually unknown from the region, a factor that has led the IUCN [International Union for Conservation of Nature] Red List of Threatened Species to categorise the species as Data Deficient (Rosa and Furtado 2007). The IUCN Red List Assessment commented on the need for more studies on the species to resolve taxonomic issues, morphology, distribution, and population dynamics (Rosa and Furtado 2007).

To address the lack of morphological and ontogenetic data on $N$. brasiliensis, a study was performed to analyse differences between the sexes in terms of body proportions and changes that occur during the growth of the species. The analyses were based on specimens from the continental shelf of southern Brazil, south-western Atlantic.

\section{Material and methods}

Specimens were collected from bycatch from the commercial bottom-pair trawlers that operate along the coast of

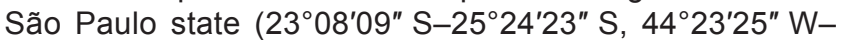
$47^{\circ} 39^{\prime} 04^{\prime \prime}$ W), south-eastern Brazil, between November 2010 and March 2012 at depths of 25 to $50 \mathrm{~m}$. The fish were frozen on board and returned to the laboratory for processing. Each specimen was identified according to de Carvalho (1999), weighed (g) and sexed, and had 43 morphological measurements taken following a modification of de Carvalho (1999). Ten 'body regions' were grouped and were considered for analysis: body, disc, gills, electric organs, eye, spiracle, mouth, nostrils, pelvic fins, and dorsal and caudal fins (Figure 1). The smaller measurements were taken using a caliper. Two additional morphometric variables were added: disc area, which was measured using an acrylic plate with $2 \mathrm{~cm} \times 2 \mathrm{~cm}$ squares; and the electric organ area, which was measured using an acrylic plate with $1 \mathrm{~cm} \times 1 \mathrm{~cm}$ squares. Hence a total of 45 variables were recorded. The electric organ from the left side of each specimen was removed from the body, weighed using a balance with precision of $0.01 \mathrm{~g}$, and the result multiplied by two in order to calculate the total weight of both organs. The concentration of the electrocytes (Figure 1f) in the electric organ was determined as the number of cells per $\mathrm{cm}^{2}$ using the $1 \mathrm{~cm} \times 1 \mathrm{~cm}$ acrylic plate.

The length-weight data were $\log _{10}$-transformed, and an analysis of covariance (ANCOVA) was performed to check for any differences between the sexes. Because no significant difference was found, embryos were then included only in the analysis of length-weight parameters for grouped sexes, because sex was not determined in all pre-natal specimens. Embryos were not considered in the remaining analyses or in the results that were based on sex determination. A $t$-test was performed to verify whether growth was isometric $(b=3)$ or allometric $(b \neq 3)$.

The relationship between electric organ weight and body weight was determined, as were the relationships between electric organ area and disc area, and between the number of electrocytes and the electric organ area. The relationship variables were log-transformed and an ANCOVA was applied to test whether there were significant differences in the parameters between males and females.

All morphometric variables except for disc area and electric organ area were expressed as a percent of the total length (TL), and a Mann-Whitney $U$-test was performed to verify the differences in the proportion of each variable between males and females. A linear regression of the log of each morphometric variable against the log of the total length was used to check the relative growth of body dimensions with respect to total length (i.e. whether the body dimensions grow at the same rate as the increase in total length). The intercept (a) and the slope (b) were tested using ANCOVA to check for significant differences in the relative growth between the sexes. The variables that showed no difference in the value of $b$ were analysed for both sexes together. When differences between the sexes were noted in $b$, the sexes were analysed separately. The allometric coefficient $(b)$ constituted the slope of the power model $y=a x^{b}$ when $\log$-transformed as $\log y=\log a+b \log x$, as proposed by Huxley (1932). An F-test was used to measure the significance of the allometric coefficient $(b)$ of each variable in relation to isometry $(b=1)$, the positive allometric coefficient $(b>1)$ and negative allometric coefficient $(b<1)$.

Juveniles and adult specimens were separated according to Gomes et al. (2010), with females being considered to have reached sexual maturity at $30 \mathrm{~cm}$ TL, and males at $25 \mathrm{~cm}$ TL. Only adults were used for multivariate analyses in order to exclude differences in growth. The matrix of the morphometric data as a percentage of TL was used to build a similarity matrix using Euclidian distances. This matrix was then used to perform a principal components analysis (PCA; scaling = 1) in order to evaluate how the objects were related. The circle of equilibrium contribution method (Legendre and Legendre 1998) showed the dimensions that made higher-than-average contributions in the PCA plot, a technique that made it possible to interpret the PCA with confidence. The radius of this circle represents the length of the vector that itself is a variable that would contribute equally to all dimensions of the PCA space. It is calculated as $\sqrt{d / p}$, in which $d$ is the number of axes represented in the plot $(d=2)$ and $p$ is the number of dimensions of the PCA space, i.e. the number of variables of the data matrix (Legendre and Legendre 1998). The variables that were inside the circle made a contribution that is less than average, and they were therefore removed from these analyses.

An analysis of similarities (ANOSIM) statistical test was then applied to check for significant differences in body proportions between the sexes. In order to determine the percentage of contribution of each morphological measurement to the overall differences, a SIMPER (similarities of percentages) analysis, with Euclidian distance, was carried out. This analysis was conducted until the cumulative differences were close to $70 \%$. Statistical analyses, except SIMPER, were performed using the computing environment $R$ ( $R$ Core Team 2014). SIMPER was conducted using the PRIMER-E ${ }^{\circledR} 6$ statistics program (Clarke 1993). 
(a)

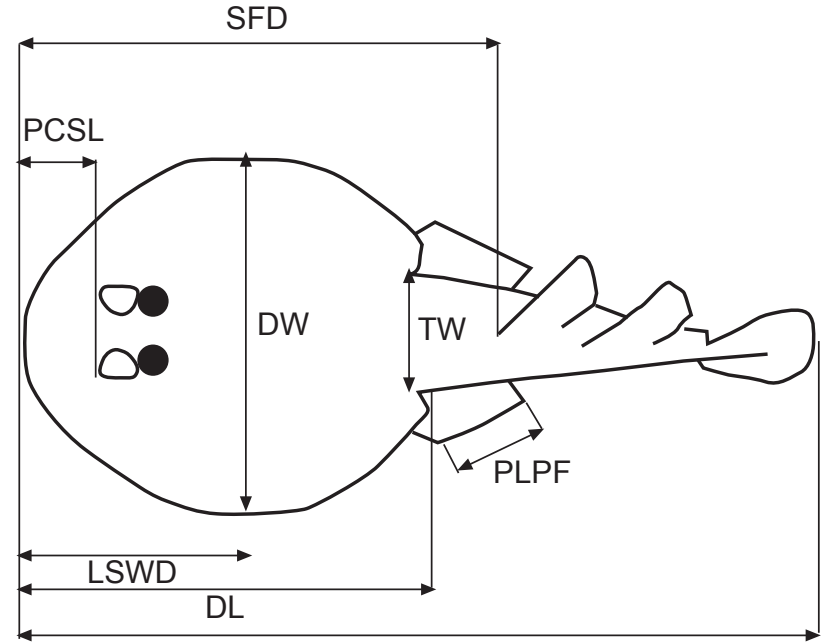

TL

(c)

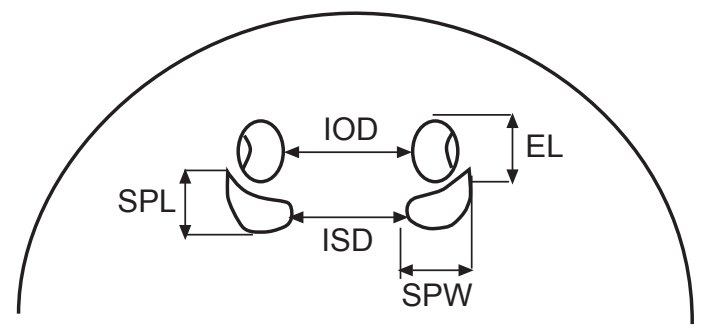

(e)

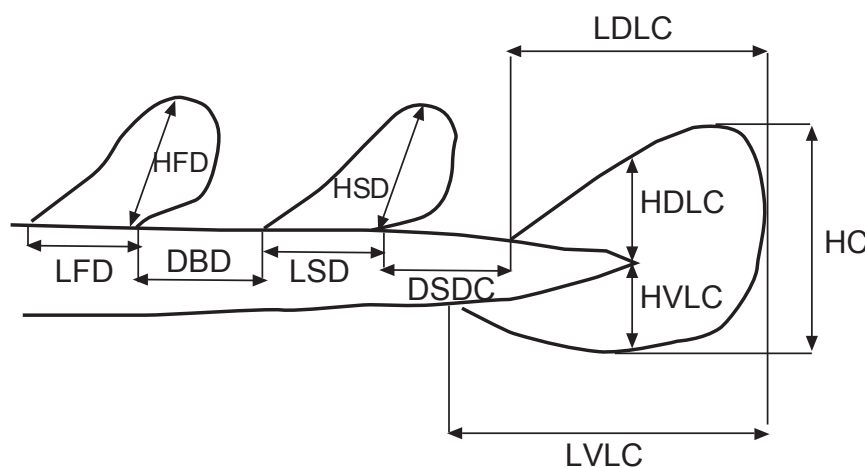

(b)

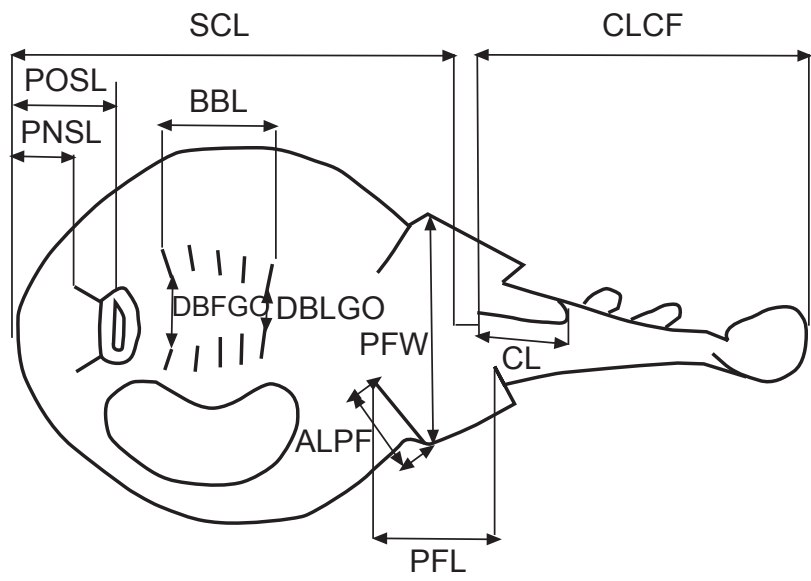

(d)

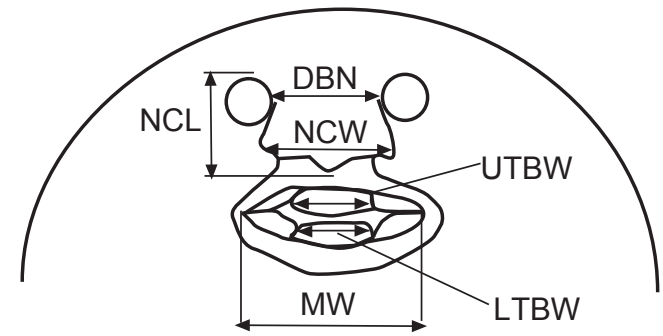

(f)

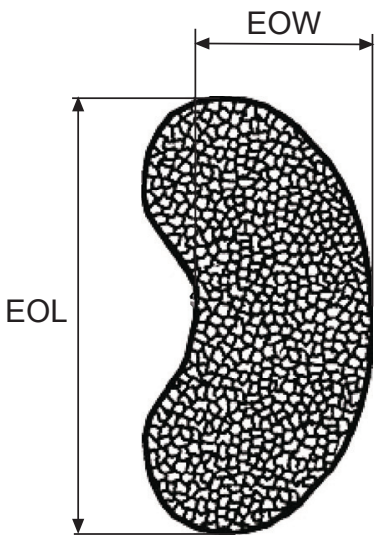

Figure 1: Morphometric measurements of Narcine brasiliensis taken for this study, showing: (a) dorsal and (b) ventral views of the body, disc, gills and pelvic fins; (c) dorsal and (d) ventral views of the anterior region, including mouth, nostrils eyes and spiracles; (e) dorsal and caudal fins; and (f) ventral view of the electric organ, including evidence of electrocyte arrangement. Body: TL (total length), SCL (snout to cloaca length), CLCF (length from cloaca to caudal fin), SFD (length from snout to first dorsal fin), LSWD (length between snout and widest part of the disc), TW (tail width), CL (clasper length). Disc: DW (disc width), DL (disc length), PCSL (preocular snout length), POSL (preoral snout length), PNSL (prenasal snout length). Gills: DBFGO (distance between first gill openings), DBLGO (distance between last gill openings), BBL (branchial basket length). Pelvic fins: PFL (pelvic fin length), PFW (pelvic fin width), ALPF (length of anterior lobe of pelvic fin), PLPF (length of posterior lobe of pelvic fin). Eyes: IOD (interorbital distance), EL (eye length). Spiracles: ISD (interspiracular distance), SPL (spiracle length), SPW (spiracle width). Mouth: MW (mouth width), UTBW (upper tooth band width), LTBW (lower tooth band width). Nostrils: NCW (nasal curtain width), NCL (nasal curtain length), DBN (distance between nostrils). Dorsal and caudal fins: HFD (height of first dorsal fin), LFD (length of first dorsal fin), HSD (height of second dorsal fin), LSD (length of second dorsal fin), LDLC (length of dorsal lobe of caudal fin), LVLC (length of ventral lobe of caudal fin), HDLC (height of dorsal lobe of caudal fin), HVLC (height of ventral lobe of caudal fin), $\mathrm{HC}$ (height of caudal fin), DBD (distance between first and second dorsal fins), DSDC (distance between second dorsal fin and caudal fin). Electric organ: EOL (electric organ length), EOW (electric organ width) 


\section{Results}

A total of 149 specimens were analysed, 33 males (236$380 \mathrm{~mm}$ TL; 119-177 mm disc width, DW), 72 females (237-470 mm TL; 118-250 mm DW), and 44 embryos (51-91 mm TL; 19-49 mm DW). The size distribution (excluding embryos) is shown in Figure 2. The lengthweight $(\mathrm{LW})$ curve $\left(W=0.000006 \mathrm{TL}^{3.1048} ; r^{2}=0.994\right)$ is represented in Figure 3. The ANCOVA for the lengthweight parameters revealed a significant difference in the intercept values ( $p=0.034, t=-2.147, F=4.654)$; however, the slopes did not differ between the sexes $(p=0.135, t=$ $-1.503, F=2.258)$. The $t$-test showed that the total sample exhibited positive allometric growth $(p<0.0001)$ with $b$ between 3.06 and 3.14 with $95 \%$ confidence.

Figure 4 illustrates the linear relationship between total electric organ weight (EOWe) and total body weight (BW) $\left(\mathrm{EOWe}=0.062 \mathrm{BW}-2.186, r^{2}=0.888\right)$. The ANCOVA showed no difference between the sexes (intercept: $p=$ $0.51, t=-0.661$; slope: $p=0.936, t=0.080)$. Total electric organ weight represented an average of $12 \%$ of body weight. The relationship between electric organ area (EOA) and disc area $(\mathrm{DA})\left(\mathrm{EOA}=0.053 \mathrm{DA}+16.610, r^{2}=0.301\right)$ is illustrated in Figure 5. There were differences between the sexes in terms of the intercept values $(t=-4.311, p=$ $\left.3.85 \times 10^{-5}\right)$ but not the slopes $(t=-0.947, p=0.346)$. The relationship between the number of cells $\mathrm{cm}^{-2}(\mathrm{NC})$ and the electric organ area $(\mathrm{EOA})\left(\mathrm{NC}=42.36 \mathrm{EOA}^{-0.48}, r^{2}=0.459\right)$ revealed a decrease in the concentration of these cells as the disc grows, although the concentration was found to stay relatively stable over the organ area range of $15-40 \mathrm{~cm}^{2}$ (Figure 6). There were no differences between sexes (intercept: $t=0.527, p=0.599$; slope: $t=-1.800, p=0.075$ ).

Significant differences between the sexes were found in 26 of the 41 relative proportions (Table 1). Proportions tended to be higher in males than females with regard to the smaller dimensions (i.e. related to dorsal and caudal fins, nostrils, eyes and mouth) and, in contrast, proportions tended to be higher in females with regard to the larger dimensions, including those of the body, disc, gills, and electric organ. Relative to growth, 28 of 41 morphometric variables used in the analysis revealed differences between males and females in the intercept (a). However, there were significant differences in the slope $(b)$ for only five variables (length from cloaca to caudal fin, tail width, electric organ length, distance between nostrils, and length of anterior lobe of pelvic fin) (Tables 2 and 3). Most morphometric variables that did not present differences between the sexes exhibited negative allometry (i.e. 20 of 36), 13 presented isometry, and three presented positive allometry. Differences in the relative growth between males and females are shown in Table 3.

Multivariate analyses were applied only to adults, and included 60 females and 27 males. The circle of equilibrium contribution selected 21 high-contribution morphometric variables (Figure 7a). The PCA graph revealed a visual difference between the sexes (Figure 7b) in which the proportion of variance accounted for by the first two axes is 0.47 . This value means that the interpretation of the first pair of axes extracts relevant information from the data.

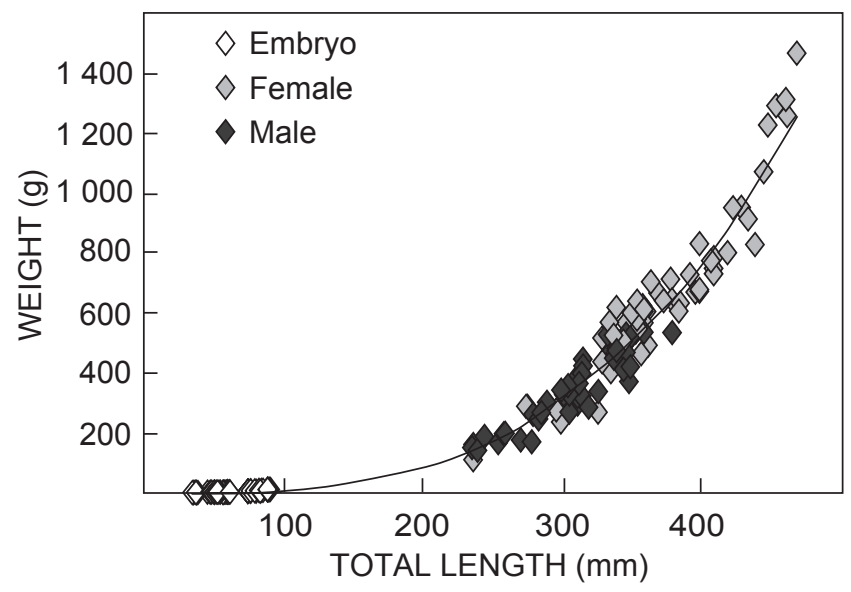

Figure 3: Length/weight relationship of total sample ( $n=149$; sexes combined and embryos included)

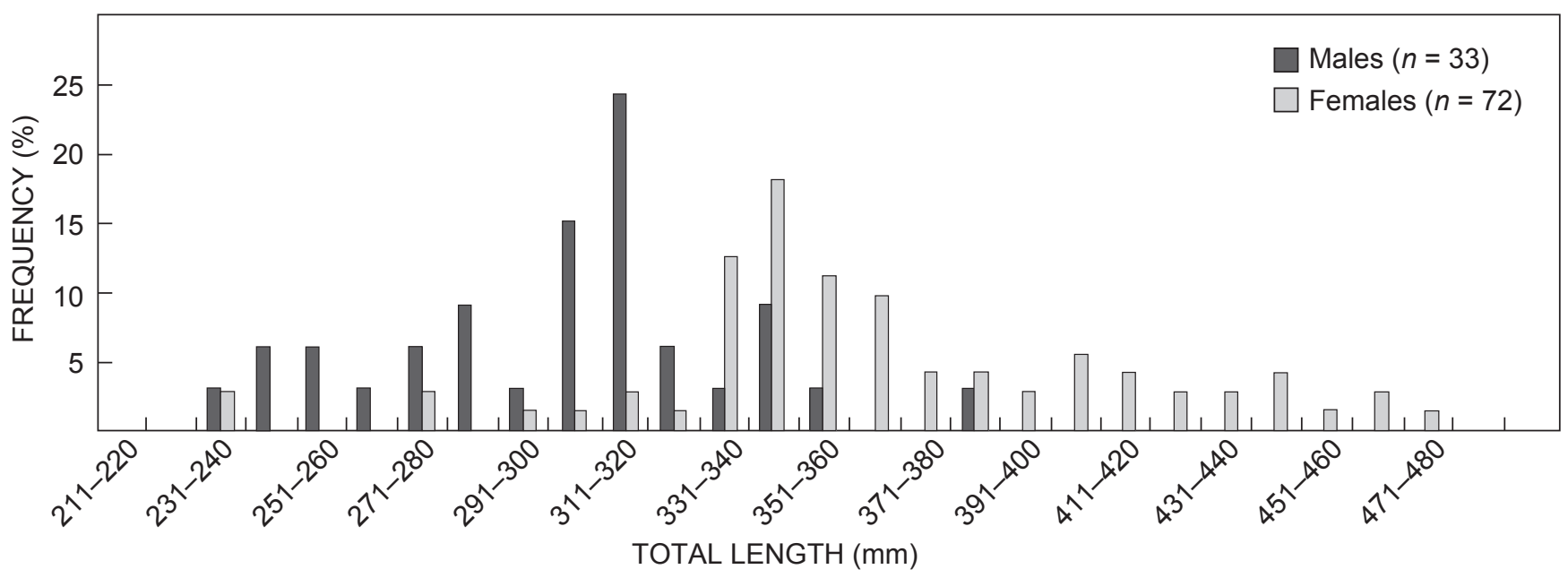

Figure 2: Size class distribution of Narcine brasiliensis males and females (embryos excluded) 
A significant difference was detected between males and females using the ANOSIM test $(r=0.483, p=0.001)$. The SIMPER analysis selected six variables with a cumulative difference of up to $70 \%$ between the sexes. The variables were tail width $(18.0 \%)$, disc width $(17.4 \%)$, length from snout to first dorsal fin $(13.0 \%)$, pelvic fin width $(8.6 \%)$, length between the snout and the widest part of the disc $(7.2 \%)$ and disc length $(5.6 \%)$.

Seven morphometric proportions - interspiracular distance, spiracle length and width, upper and lower tooth band width, pelvic fin length, and length of posterior lobe of pelvic fin did not differ between sexes or with growth, indicating that these dimensions are stable for the species.

\section{Discussion}

Based on the 105 specimens of $N$. brasiliensis studied here, females were found to reach larger sizes than males -470 and $380 \mathrm{~mm}$ TL, respectively. This was also observed in other studies of this species (Martins et al. 2009; Ferreira

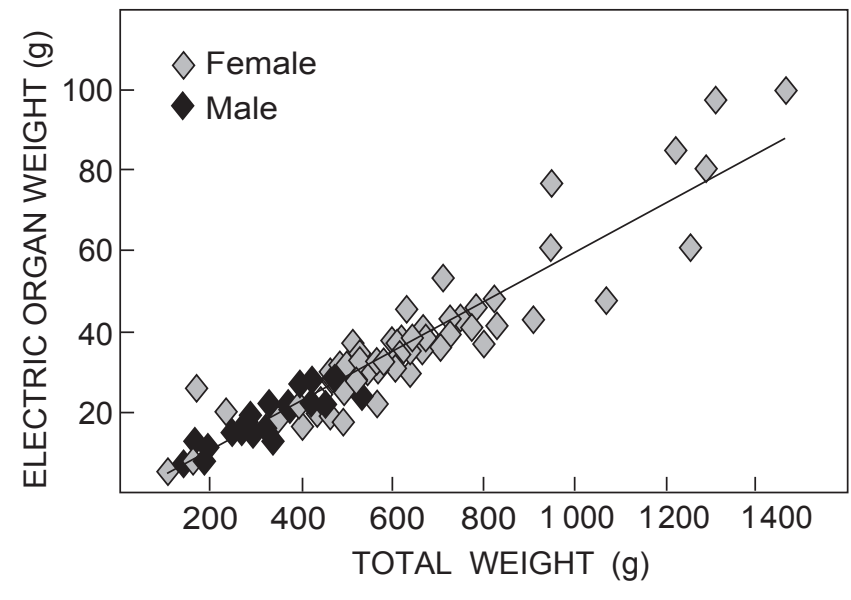

Figure 4: Relationship between electric organ weight and total body weight $(n=105)$

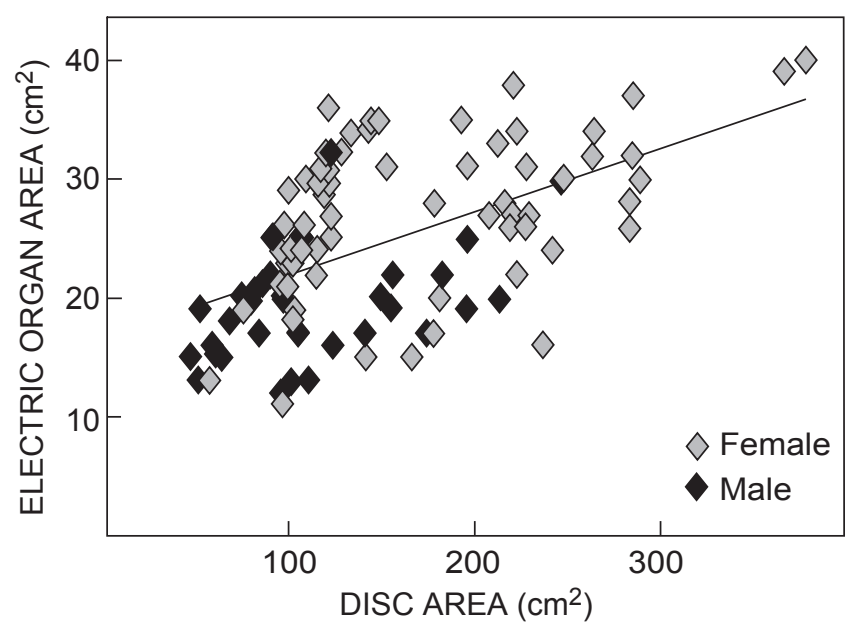

Figure 5: Relationship between electric organ area and disc area $(n=101)$ and Vooren 2012). A frequently observed larger size in female elasmobranchs facilitates the accommodation and nourishment of embryos (Hamlett 2005). Increased fecundity with increasing maternal size is also well documented (Cortes 2000; Consalvo et al. 2007), which is consistent with conferring a selective advantage on largersized females.

Published estimates of length-weight relationship parameters for $N$. brasiliensis are lacking. In the present study, an estimate was based on 149 individuals, including embryos. No differences were found between the sexes, and positive allometry was evident.

Measurements taken in this study followed de Carvalho (1999) and the ranges of most body proportions were within those that he reported. The ranges found for disc length, distance between first gill openings, length of posterior lobe of pelvic fin, tail width, snout to cloaca length, length from the cloaca to the caudal fin, and length from the snout to the first dorsal fin, all differed from those reported by de Carvalho (1999), although the highest difference found was $5 \%$ (for length of posterior lobe of pelvic fin). These differences may be a result of sample size or the size distribution of the sample; de Carvalho (1999) examined individuals from 107 to $445 \mathrm{~mm}$ TL, whereas the range in the current study was $236-470 \mathrm{~mm}$. We observed that some proportions changed as the specimens grew in length. Measurement error may have been a factor because measurements were taken by different people and specimens were measured either before or after preservation.

Mathewson et al. (1958) noted that the relative proportions of electric organs for $N$. bancroftii (reported at the time to be $N$. brasiliensis) represented $20 \%$ of the total body weight. In the current study, however, these structures were found to represent only $12 \%$ of the total weight, a considerable difference that can probably be explained in taxonomic terms, because the study animals in each case are now considered two distinct species. The relationship between body size and the number of cells in the electric organs is similar between the two

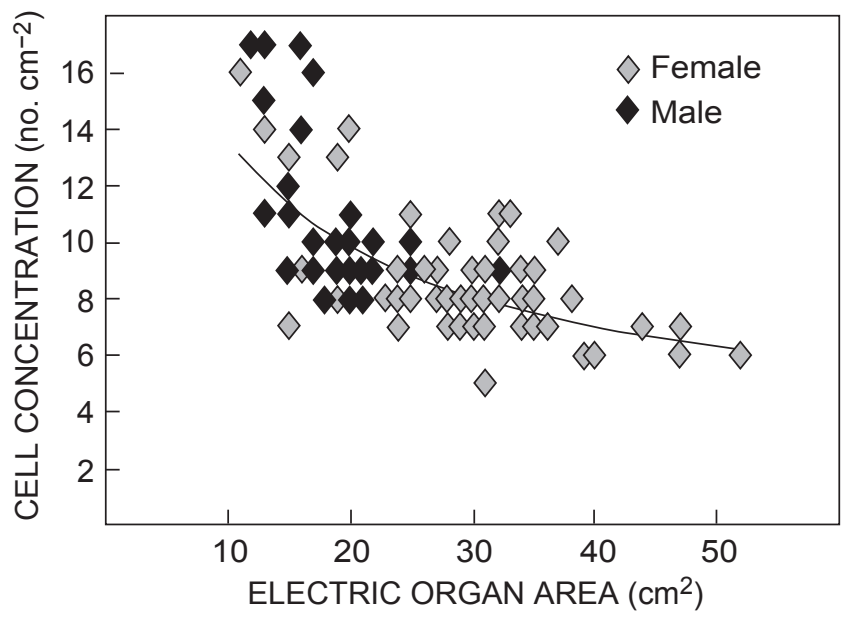

Figure 6: Relationship between cell concentration and the electric organ area $(n=100)$ 
species. Macesic and Kajiura (2009) studied N. bancroftii (reported as $N$. brasiliensis) from the western North Atlantic, and found that the number and size of the cells in the electric organ were higher in adults than in newborns and embryos, because the surface area increased as the disc width increased. Similarly, the present study showed that the electric organ area in $N$. brasiliensis increases with disc area. However, in our study the concentration of electrocytes (hexagonal cells of the electric organ) decreased with increasing electric organ area, suggesting proportionally larger cells. In addition, our data did not show a significant difference between the sexes in terms of the relationship between electric organ weight and body weight, in contrast to the finding of Macesic and Kajiura (2009) that males had heavier electric organs than females.

Features such as eyes, mouth, and nostrils were larger in males. This may indicate the retention of some juvenile

Table 1: Morphometric characterisation of males and females of Narcine brasiliensis and results of Mann-Whitney U-tests. Other than total length (TL), disc area (DA) and electric organ area (EOA), variables (defined in Figure 1) are expressed as a percentage of TL. SD = standard deviation; $U$ = test statistic

\begin{tabular}{|c|c|c|c|c|c|c|c|c|c|}
\hline \multirow{2}{*}{ Region } & \multirow{2}{*}{ Dimension } & \multicolumn{3}{|c|}{ Females $(n=72)$} & \multicolumn{3}{|c|}{ Males $(n=33)$} & \multirow{2}{*}{$U$} & \multirow{2}{*}{$p$} \\
\hline & & Mean & Range & SD & Mean & Range & SD & & \\
\hline Reference length & $\mathrm{TL}(\mathrm{mm})$ & 364.2 & $237-470$ & 48.5 & 301.7 & $236-380$ & 34.0 & & \\
\hline Reference area & $\mathrm{DA}\left(\mathrm{cm}^{2}\right)$ & 169.3 & $56-380$ & 71.9 & 108.5 & $47-213$ & 46.2 & & \\
\hline Reference area & $\mathrm{EOA}\left(\mathrm{cm}^{2}\right)$ & 28.3 & $11-52$ & 7.8 & 19.1 & $12-32$ & 4.3 & & \\
\hline \multirow[t]{6}{*}{ Body } & SCL & 49.8 & $44.8-53.3$ & 1.3 & 48.9 & $46.2-54.1$ & 1.8 & 1938.5 & $2.2 \times 10^{-7 *}$ \\
\hline & CLCF & 45.9 & $41.4-52.1$ & 1.6 & 47.6 & $45.2-53.6$ & 1.7 & 488.0 & $1.4 \times 10^{-6 *}$ \\
\hline & SFD & 64.7 & $57.9-71.2$ & 1.7 & 62.6 & $58.1-64.7$ & 1.2 & 2238.0 & $4.3 \times 10^{-13 *}$ \\
\hline & LSWD & 28.8 & $23.6-32.2$ & 1.7 & 29.1 & $25.8-32.6$ & 1.7 & 1101.0 & 0.55 \\
\hline & TW & 22.5 & $19.4-25.0$ & 1.4 & 19.8 & $13.8-23.7$ & 1.8 & 2171.0 & $1.2 \times 10^{-11 *}$ \\
\hline & $\mathrm{CL}$ & - & - & - & 18.8 & $12.5-23.8$ & 1.9 & - & - \\
\hline \multirow[t]{5}{*}{ Disc } & DW & 51.4 & $45.2-55.9$ & 2.3 & 49.6 & $46.1-53.4$ & 2.2 & 1720.0 & $2.4 \times 10^{-4 *}$ \\
\hline & $\mathrm{DL}$ & 47.7 & $42.1-50.7$ & 1.7 & 47.6 & $43.6-57.6$ & 2.3 & 1410.0 & 0.13 \\
\hline & PCSL & 12.1 & $10.1-13.9$ & 0.7 & 12.2 & $10.2-14.0$ & 0.8 & 1052.0 & 0.35 \\
\hline & POSL & 13.8 & $10.9-16.0$ & 0.8 & 14.2 & $11.6-16.1$ & 1.0 & 836.0 & $0.02^{*}$ \\
\hline & PNSL & 11.6 & $9.8-13.1$ & 0.7 & 11.8 & $9.3-13.6$ & 0.9 & 975.5 & 0.14 \\
\hline \multirow[t]{3}{*}{ Gills } & DBFGO & 14.7 & $13.5-16.7$ & 0.7 & 14.1 & $10.7-15.7$ & 1.1 & 1609.0 & $3.7 \times 10^{-3 *}$ \\
\hline & DBLGO & 9.0 & $6.4-10.9$ & 0.8 & 7.8 & $6.6-9.2$ & 0.7 & 2063.5 & $1.5 \times 10^{-9 *}$ \\
\hline & $\mathrm{BBL}$ & 10.1 & $8.0-11.1$ & 0.6 & 10.2 & $8.9-11.7$ & 0.6 & 1051.5 & 0.35 \\
\hline \multirow[t]{2}{*}{ Electric organ } & EOL & 24.4 & 21.6-27.2 & 1.1 & 24.1 & $20.6-29.2$ & 1.8 & 1377.0 & 0.19 \\
\hline & EOW & 11.5 & $9.2-13.8$ & 0.9 & 10.6 & $8.5-13.2$ & 1.0 & 1792.5 & $3.0 \times 10^{-5 *}$ \\
\hline \multirow[t]{2}{*}{ Eye } & IOD & 7.2 & $5.4-8.2$ & 0.5 & 7.0 & $6.1-8.1$ & 0.5 & 1607.0 & $3.9 \times 10^{-3 *}$ \\
\hline & EL & 2.6 & $1.7-4.7$ & 0.4 & 2.8 & $1.8-3.8$ & 0.5 & 638.0 & $1.5 \times 10^{-4^{*}}$ \\
\hline \multirow[t]{3}{*}{ Spiracle } & ISD & 7.5 & $6.0-8.5$ & 0.6 & 7.5 & $5.8-8.6$ & 0.6 & 1274.5 & 0.55 \\
\hline & SPL & 2.0 & $1.1-3.1$ & 0.4 & 1.9 & $1.2-2.7$ & 0.4 & 1382.5 & 0.18 \\
\hline & SPW & 2.1 & $1.4-2.8$ & 0.3 & 2.0 & $1.2-2.7$ & 0.4 & 1317.0 & 0.38 \\
\hline \multirow[t]{3}{*}{ Mouth } & $\mathrm{MW}$ & 5.6 & $4.6-6.8$ & 0.5 & 6.0 & $5.1-7.4$ & 0.5 & 775.0 & $4.4 \times 10^{-3 *}$ \\
\hline & UTBW & 3.0 & $2.5-4.0$ & 0.3 & 3.0 & $2.3-3.5$ & 0.3 & 1090.0 & 0.50 \\
\hline & LTBW & 3.0 & $2.4-4.0$ & 0.3 & 3.0 & $2.5-3.5$ & 0.3 & 1116.0 & 0.62 \\
\hline \multirow[t]{3}{*}{ Nostril } & NCW & 5.6 & $4.7-6.4$ & 0.4 & 6.1 & $4.4-6.8$ & 0.5 & 363.0 & $1.2 \times 10^{-8 *}$ \\
\hline & $\mathrm{NCL}$ & 2.1 & $1.5-2.9$ & 0.3 & 2.6 & $1.7-3.4$ & 0.4 & 478.0 & $9.7 \times 10^{-7 *}$ \\
\hline & DBN & 5.7 & $4.7-7.6$ & 0.4 & 6.1 & $4.1-7.1$ & 0.6 & 431.0 & $1.8 \times 10^{-7 *}$ \\
\hline \multirow[t]{4}{*}{ Pelvic fin } & PFL & 23.8 & $18.4-27.2$ & 1.6 & 23.9 & $17.1-27.6$ & 2.6 & 1027.5 & 0.27 \\
\hline & PFW & 36.6 & $31.0-39.6$ & 1.6 & 35.4 & $31.2-38.1$ & 1.5 & 1753.5 & $9.7 \times 10^{-5 *}$ \\
\hline & ALPF & 11.1 & $9.0-14.1$ & 1.2 & 11.2 & $8.7-13.9$ & 1.1 & 1108.0 & 0.58 \\
\hline & PLPF & 24.6 & $19.3-30.1$ & 2.2 & 24.6 & $17.9-29.7$ & 1.5 & 1133.0 & 0.71 \\
\hline \multirow{11}{*}{$\begin{array}{l}\text { Dorsal and } \\
\text { caudal fins }\end{array}$} & HFD & 9.9 & $8.0-11.6$ & 0.7 & 10.8 & $8.6-12.1$ & 0.8 & 444.0 & $2.8 \times 10^{-7 *}$ \\
\hline & LFD & 6.9 & $5.4-7.6$ & 0.4 & 7.3 & $6.4-8.3$ & 0.4 & 594.5 & $4.2 \times 10^{-5 *}$ \\
\hline & HSD & 10.0 & $7.8-11.9$ & 0.8 & 10.9 & $8.7-12.8$ & 0.9 & 510.0 & $2.9 \times 10^{-6 *}$ \\
\hline & LSD & 7.0 & $6.0-8.2$ & 0.4 & 7.4 & $6.8-8.2$ & 0.3 & 573.0 & $2.2 \times 10^{-5 *}$ \\
\hline & LDLC & 12.1 & $10.8-14.2$ & 0.7 & 13.1 & $11.5-14.8$ & 0.6 & 357.5 & $1.0 \times 10^{-8 *}$ \\
\hline & LVLC & 13.7 & $11.7-15.5$ & 0.8 & 14.8 & $12.8-16.2$ & 0.9 & 405.0 & $6.6 \times 10^{-8 *}$ \\
\hline & HDLC & 5.8 & $4.6-7.0$ & 0.5 & 6.6 & $4.9-8.2$ & 0.6 & 343.0 & $5.6 \times 10^{-9 *}$ \\
\hline & HVLC & 4.6 & $3.4-5.6$ & 0.5 & 5.1 & $3.9-6.3$ & 0.6 & 621.0 & $9.2 \times 10^{-5 *}$ \\
\hline & $\mathrm{HC}$ & 12.2 & $10.2-13.9$ & 0.8 & 13.5 & $12.2-15.9$ & 0.9 & 314.0 & $1.6 \times 10^{-9 *}$ \\
\hline & DBD & 4.5 & $2.9-6.3$ & 0.6 & 5.0 & $3.8-6.1$ & 0.7 & 715.5 & $1.1 \times 10^{-3 *}$ \\
\hline & DSDC & 4.3 & $2.6-6.1$ & 0.7 & 4.5 & $3.1-5.8$ & 0.7 & 906.0 & 0.05 \\
\hline
\end{tabular}

* Denotes significant difference $(p<0.05)$ 
Table 2: Regressions and F-test analysis of the allometric coefficient $(b)$ in relation to isometry $(b=1)$ for the variables (defined in Figure 1$)$ that did not differ between the sexes in terms of the allometric coefficient. Analysis of covariance (ANCOVA) was used to test for differences between the sexes in terms of the intercept $(a)$ and the slope $(b) ; r^{2}=$ coefficient of determination; $F=$ test statistic; $-\mathrm{A}=$ negative allometry, $+\mathrm{A}=$ positive allometry, $\mathrm{I}=$ isometry; $t=$ test statistic

\begin{tabular}{|c|c|c|c|c|c|c|c|c|c|}
\hline \multirow{3}{*}{ Region } & \multirow{3}{*}{ Regression } & \multirow{3}{*}{$r^{2}$} & \multirow{2}{*}{\multicolumn{2}{|c|}{$F$-test }} & \multirow{3}{*}{ Growth } & \multicolumn{4}{|c|}{ ANCOVA } \\
\hline & & & & & & \multicolumn{2}{|c|}{ Intercept (a) } & \multicolumn{2}{|c|}{ Slope $(b)$} \\
\hline & & & $F$ & $p$ & & $t$ & $p$ & $t$ & $p$ \\
\hline \multirow[t]{3}{*}{ Body } & $\mathrm{SCL}=-0.840+1.023 \mathrm{TL}$ & 0.96 & 1.43 & 0.235 & 1 & -2.72 & 0.008 & 1.10 & 0.273 \\
\hline & $\mathrm{SFD}=-0.738+1.050 \mathrm{TL}$ & 0.97 & 8.02 & 0.006 & $+\mathrm{A}$ & -5.71 & $1.12 \times 10^{-7}$ & -1.18 & 0.241 \\
\hline & LSWD $=-0.560+0.883 \mathrm{TL}$ & 0.86 & 10.77 & $1.41 \times 10^{-3}$ & $-\mathrm{A}$ & -1.36 & 0.176 & 1.26 & 0.212 \\
\hline \multirow[t]{5}{*}{ Disc } & $\mathrm{DW}=-0.911+1.040 \mathrm{TL}$ & 0.92 & 1.88 & 0.173 & 1 & -3.74 & $3.0 \times 10^{-4}$ & -0.92 & 0.360 \\
\hline & $\mathrm{DL}=-0.364+0.935 \mathrm{TL}$ & 0.94 & 7.33 & 0.008 & $-\mathrm{A}$ & -2.58 & 0.011 & -1.05 & 0.295 \\
\hline & $\mathrm{PCSL}=-1.116+0.829 \mathrm{TL}$ & 0.84 & 22.56 & $6.61 \times 10^{-6}$ & $-\mathrm{A}$ & -2.50 & 0.014 & -0.31 & 0.758 \\
\hline & $\mathrm{POSL}=-0.694+0.780 \mathrm{TL}$ & 0.83 & 38.73 & $1.06 \times 10^{-8}$ & $-\mathrm{A}$ & -1.50 & 0.137 & -0.85 & 0.395 \\
\hline & $\mathrm{PNSL}=-0.738+0.757 \mathrm{TL}$ & 0.81 & 45.99 & $7.66 \times 10^{-10}$ & $-\mathrm{A}$ & -3.05 & 0.003 & -0.02 & 0.988 \\
\hline \multirow[t]{3}{*}{ Gills } & $\mathrm{DBFGO}=-2.315+1.066 \mathrm{TL}$ & 0.88 & 2.99 & 0.086 & I & -3.40 & $9.7 \times 10^{-4}$ & -0.93 & 0.355 \\
\hline & $\mathrm{DBLGO}=-4.338+1.322 \mathrm{TL}$ & 0.80 & 25.22 & $2.15 \times 10^{-6}$ & $+A$ & -5.21 & $9.9 \times 10^{-7}$ & -1.03 & 0.304 \\
\hline & $\mathrm{BBL}=-1.628+0.886 \mathrm{TL}$ & 0.85 & 9.86 & $2.20 \times 10^{-3}$ & $-\mathrm{A}$ & -0.67 & 0.502 & -0.62 & 0.534 \\
\hline Electric organ & $\mathrm{EOW}=-2.905+1.122 \mathrm{TL}$ & 0.79 & 4.52 & 0.036 & $+\mathrm{A}$ & -3.79 & $2.6 \times 10^{-4}$ & -0.63 & 0.533 \\
\hline \multirow{2}{*}{ Eye } & $\mathrm{IOD}=-2.533+0.982 \mathrm{TL}$ & 0.80 & 0.14 & 0.71 & I & -3.20 & 0.002 & 0.48 & 0.635 \\
\hline & $E L=-1.858+0.694 T L$ & 0.32 & 9.35 & $2.85 \times 10^{-3}$ & $-\mathrm{A}$ & 1.64 & 0.104 & 2.11 & 0.038 \\
\hline \multirow[t]{3}{*}{ Spiracle } & $\mathrm{ISD}=-2.104+0.917 \mathrm{TL}$ & 0.77 & 2.77 & 0.098 & I & -1.53 & 0.129 & -0.93 & 0.353 \\
\hline & $\mathrm{SPL}=-4.231+1.051 \mathrm{TL}$ & 0.39 & 0.16 & 0.689 & I & -1.40 & 0.164 & 1.42 & 0.160 \\
\hline & $S P W=-4.263+1.061 T L$ & 0.48 & 0.32 & 0.57 & I & -0.52 & 0.606 & 1.19 & 0.238 \\
\hline \multirow[t]{3}{*}{ Mouth } & $M W=-2.560+0.948 T L$ & 0.74 & 0.88 & 0.349 & I & 3.37 & 0.001 & -0.29 & 0.775 \\
\hline & UTBW $=-4.210+1.122 \mathrm{TL}$ & 0.75 & 3.68 & 0.058 & I & 1.02 & 0.309 & -0.89 & 0.377 \\
\hline & $\mathrm{LTBW}=-3.732+1.039 \mathrm{TL}$ & 0.75 & 0.42 & 0.518 & 1 & 1.08 & 0.282 & -0.52 & 0.606 \\
\hline \multirow[t]{2}{*}{ Nostrils } & $\mathrm{NCW}=-1.652+0.793 \mathrm{TL}$ & 0.71 & 17.37 & $6.41 \times 10^{-5}$ & $-\mathrm{A}$ & 4.47 & $2.4 \times 10^{-5}$ & 1.76 & 0.082 \\
\hline & $\mathrm{NCL}=-1.772+0.652 \mathrm{TL}$ & 0.28 & 11.48 & $9.99 \times 10^{-4}$ & $-\mathrm{A}$ & 4.78 & $6.0 \times 10^{-6}$ & 0.44 & 0.660 \\
\hline \multirow[t]{3}{*}{ Pelvic fin } & $\mathrm{PFL}=-1.531+1.016 \mathrm{TL}$ & 0.77 & 0.08 & 0.771 & 1 & 0.24 & 0.814 & 1.63 & 0.105 \\
\hline & $\mathrm{PFW}=-1.343+1.056 \mathrm{TL}$ & 0.93 & 3.76 & 0.055 & I & -3.00 & 0.003 & -0.54 & 0.588 \\
\hline & PLPF $=-2.024+1.106 \mathrm{TL}$ & 0.72 & 2.47 & 0.119 & I & 0.78 & 0.438 & 0.57 & 0.573 \\
\hline \multirow{11}{*}{$\begin{array}{l}\text { Dorsal and } \\
\text { caudal fins }\end{array}$} & $\mathrm{HFD}=-1.256+0.823 \mathrm{TL}$ & 0.71 & 11.87 & $8.28 \times 10^{-4}$ & $-\mathrm{A}$ & 4.46 & $2.1 \times 10^{-5}$ & 1.03 & 0.305 \\
\hline & $\mathrm{LFD}=-1.724+0.839 \mathrm{TL}$ & 0.82 & 17.12 & $7.18 \times 10^{-5}$ & $-\mathrm{A}$ & 2.66 & 0.009 & 0.66 & 0.511 \\
\hline & $\mathrm{HSD}=-1.320+0.836 \mathrm{TL}$ & 0.70 & 9.21 & 0.003 & $-\mathrm{A}$ & 3.66 & $3.9 \times 10^{-4}$ & 0.76 & 0.451 \\
\hline & $\mathrm{LSD}=-1.817+0.859 \mathrm{TL}$ & 0.86 & 17.07 & $7.33 \times 10^{-5}$ & $-\mathrm{A}$ & 2.66 & 0.009 & 1.11 & 0.269 \\
\hline & LDLC $=-0.913+0.798 T L$ & 0.83 & 32.12 & $1.32 \times 10^{-7}$ & $-\mathrm{A}$ & 4.23 & $5.2 \times 10^{-5}$ & 0.39 & 0.696 \\
\hline & LVLC $=-0.521+0.752 T L$ & 0.79 & 41.85 & $3.37 \times 10^{-9}$ & $-\mathrm{A}$ & 3.57 & $5.4 \times 10^{-4}$ & 0.92 & 0.361 \\
\hline & $\mathrm{HDLC}=-1.918+0.847 \mathrm{TL}$ & 0.63 & 5.73 & 0.018 & $-\mathrm{A}$ & 6.22 & $1.1 \times 10^{-8}$ & 1.12 & 0.265 \\
\hline & HVLC $=-2.275+0.867 \mathrm{TL}$ & 0.57 & 3.20 & 0.076 & $-\mathrm{A}$ & 3.92 & $1.6 \times 10^{-4}$ & 0.20 & 0.842 \\
\hline & $\mathrm{HC}=-0.974+0.811 \mathrm{TL}$ & 0.72 & 14.72 & $2.15 \times 10^{-4}$ & $-\mathrm{A}$ & 5.92 & $4.4 \times 10^{-8}$ & 1.25 & 0.215 \\
\hline & $\mathrm{DBD}=-2.352+0.876 \mathrm{TL}$ & 0.47 & 1.86 & 0.175 & $-\mathrm{A}$ & 3.26 & 0.002 & 1.37 & 0.175 \\
\hline & $\mathrm{DSDC}=-2.750+0.932 \mathrm{TL}$ & 0.44 & 0.43 & 0.514 & $-\mathrm{A}$ & 1.80 & 0.075 & -1.21 & 0.227 \\
\hline
\end{tabular}

Table 3: Regression slopes and $F$-test analysis of the allometric coefficient $(b)$ in relation to isometry $(b=1)$ for the variables $($ defined in Figure 1) that differed between the sexes in terms of the allometric coefficient (b). Analysis of covariance (ANCOVA) was used to test for differences between the sexes in terms of the intercept $(a)$ and the slope $(b) . \mathrm{F}=$ female, $\mathrm{M}=$ male, $r^{2}=$ coefficient of determination, $F=$ test statistic, $-\mathrm{A}=$ negative allometry, $+\mathrm{A}=$ positive allometry, $\mathrm{I}=$ isometry, $t=$ test statistic

\begin{tabular}{|c|c|c|c|c|c|c|c|c|c|c|}
\hline \multirow[b]{2}{*}{ Region } & \multirow[b]{2}{*}{ Sex } & \multirow[b]{2}{*}{ Regression } & \multirow[b]{2}{*}{$r^{2}$} & \multirow{2}{*}{\multicolumn{2}{|c|}{$F$-test }} & \multirow[b]{2}{*}{ Growth } & \multicolumn{4}{|c|}{ ANCOVA } \\
\hline & & & & & & & \multicolumn{2}{|c|}{ Intercept (a) } & \multicolumn{2}{|c|}{ Slope $(b)$} \\
\hline Body* $^{*}$ & $\begin{array}{l}\mathrm{F} \\
\mathrm{M}\end{array}$ & $\begin{array}{l}\mathrm{CLCF}=-0.580+0.966 \mathrm{TL} \\
\mathrm{CLCF}=-1.599+1.150 \mathrm{TL}\end{array}$ & $\begin{array}{l}0.94 \\
0.95\end{array}$ & $\begin{array}{l}1.35 \\
9.98\end{array}$ & $\begin{array}{l}0.248 \\
0.003\end{array}$ & $\begin{array}{c}1 \\
+A\end{array}$ & 4.41 & $2.5 \times 10^{-5}$ & 3.18 & 0.002 \\
\hline & $\begin{array}{l}\mathrm{F} \\
\mathrm{M}\end{array}$ & $\begin{array}{l}\mathrm{TW}=-2.579+1.184 \mathrm{TL} \\
\mathrm{TW}=-1.196+0.925 \mathrm{TL}\end{array}$ & $\begin{array}{l}0.90 \\
0.55\end{array}$ & $\begin{array}{r}15.19 \\
0.25\end{array}$ & $\begin{array}{l}2.20 \times 10^{-4} \\
0.620\end{array}$ & $\begin{array}{c}+\mathrm{A} \\
\mathrm{I}\end{array}$ & -5.92 & $4.4 \times 10^{-8}$ & -2.08 & 0.040 \\
\hline Electric organ & $\begin{array}{l}\mathrm{F} \\
\mathrm{M}\end{array}$ & $\begin{array}{l}\mathrm{EOL}=-0.915+0.915 \mathrm{TL} \\
\mathrm{EOL}=0.190+0.717 \mathrm{TL}\end{array}$ & $\begin{array}{l}0.89 \\
0.61\end{array}$ & $\begin{array}{l}4.71 \\
7.58\end{array}$ & $\begin{array}{l}0.033 \\
0.010\end{array}$ & $\begin{array}{l}-\mathrm{A} \\
-\mathrm{A}\end{array}$ & -2.60 & 0.012 & -2.13 & 0.035 \\
\hline Pelvic fin & $\begin{array}{l}F \\
M\end{array}$ & $\begin{array}{l}\mathrm{ALPF}=-1.213+0.832 \mathrm{TL} \\
\mathrm{ALPF}=-3.367+1.206 \mathrm{TL}\end{array}$ & $\begin{array}{l}0.54 \\
0.66\end{array}$ & $\begin{array}{l}3.34 \\
1.81\end{array}$ & $\begin{array}{l}0.072 \\
0.188\end{array}$ & $\begin{array}{c}-A \\
1\end{array}$ & -0.14 & 0.886 & 2.04 & 0.044 \\
\hline
\end{tabular}

${ }^{*}$ Note that $\mathrm{CL}$ exhibited isometric growth in males $\left(\mathrm{CL}=-2.948+1.223 \mathrm{TL} ; r^{2}=0.64 ; F=1.82 ; p=0.87\right)$ 

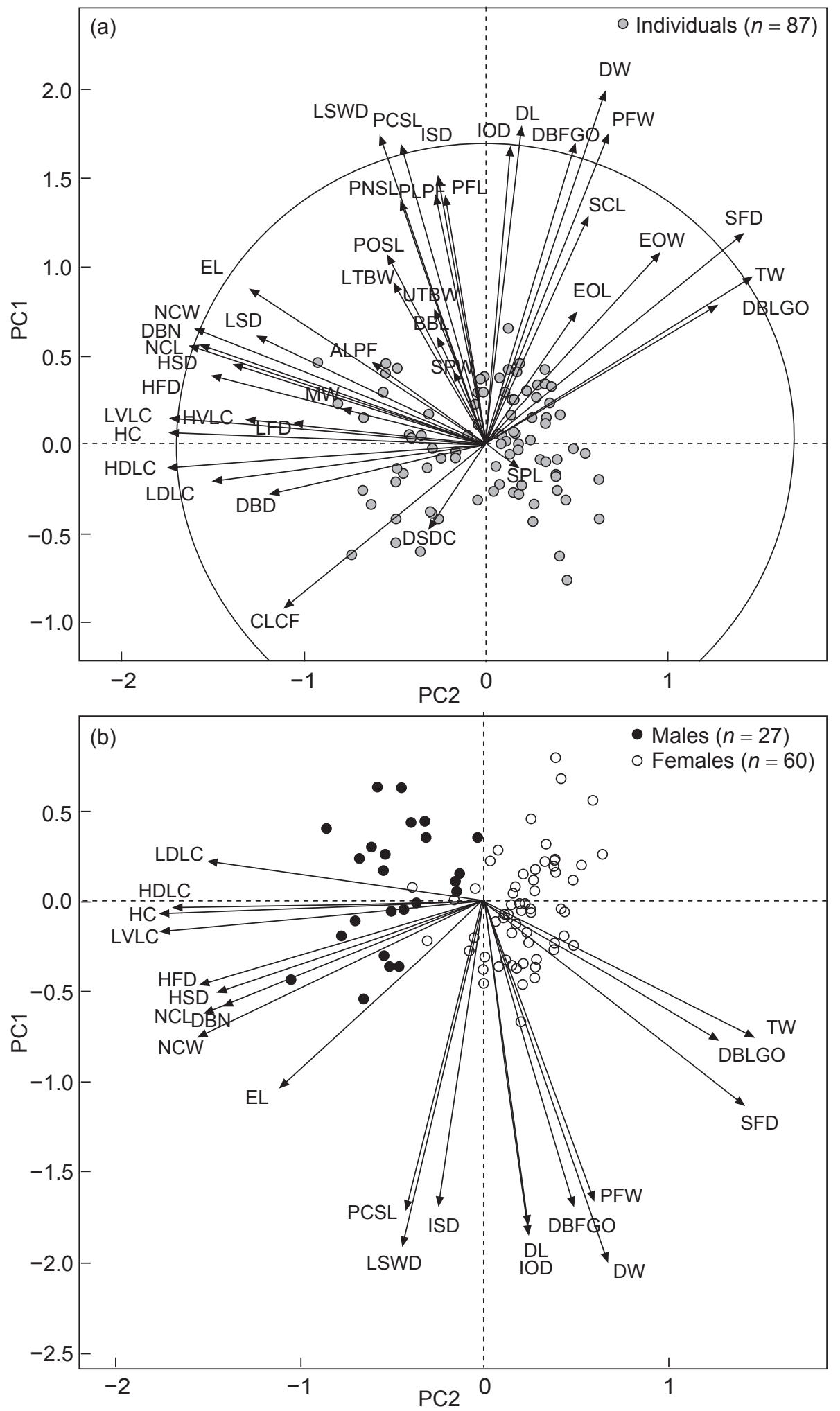

Figure 7: PCA plots with the measurements taken in this study (defined in Figure 1) showing (a) the circle of equilibrium contribution, with 21 high-contribution variables selected by falling outside the circle (the value of each dimension is indicated by the position of its label); and (b) the difference in body form between the sexes, illustrated in terms of the 21 selected variables 
traits, given the male's smaller size at maturity, or may reflect a behavioural difference between the sexes. This subject requires further investigation.

Although there are few studies of ontogenetic changes in morphometric variables in elasmobranchs, Garrick (1960) noted that measurements within the cephalic and caudal regions of six species of the dogfish genus Squalus (Squalidae) exhibited low rates of growth compared to TL (negative allometry), while the trunk exhibited positive allometry. In the present study, the cephalic region, represented here by disc length or by the length between the snout and the widest part of the disc, also grew at a lower rate than did TL. However, the posterior region (distance from cloaca to caudal fin) presented isometry in females and positive allometry in males. These differences are likely related to the elongated body form of the demersal-pelagic and relatively active sharks studied by Garrick (1960) and the dorso-ventrally compressed body of the benthic $N$. brasiliensis.

According to Koehl (1996), external morphology influences the performance of an organism in the environment, and, more specifically, the skills required to perform a given function. Hence we suggest that the morphological differences between sexes in this study may reflect more active behaviour in males that facilitates the search for females. First, the posterior region (the length from the cloaca to the caudal fin) develops at the same rate as TL in females and at a faster rate in males, which display a proportionately longer tail. Second, males present higher values of the proportions of the dorsal fins and the superior lobe of the caudal fin, which might confer improved hydrodynamics, given that fins are useful for stabilising swimming movements. All Narcinidae species are thought to swim by axial undulation (Schaefer and Summers 2005), which is performed by the tail. Rosenblum et al. (2011), in their study on $N$. bancroftii (reported as $N$. brasiliensis), did not report on differences in swimming patterns between the sexes but they did state the importance of the tail for propulsive movements during horizontal swimming and gliding. Third, the anterior lobe of the pelvic fin develops at a higher rate in males, a factor that implies more active locomotion. Macesic and Kajiura (2010) showed that N. bancroftii has one of the largest pelvic fin areas of benthic batoids, and has specialised musculature to support it. These muscles move the jointed propterygia, and thus allow for punting movements. The propterygium is located in the anterior lobe of the pelvic fin and its isometrical development in males - contrasting with negative allometry in females - may enhance punting performance in males. Tail width displayed positive allometry in females and isometry in males, resulting in a proportionally wider trunk in females (and contributing to the difference between males and females in the SIMPER analysis). This difference is probably explained by the need for a larger abdomen in females in order to accommodate embryos. Bass (1973) also suggested this in a study of several sharks in which female abdomens were longer than those of the males.

Based on multivariate analyses it is possible to conclude that the body form of $N$. brasiliensis differs between adult males and females. Some variables were found to contribute more than others to this difference, particularly disc width, tail width and the distance from the snout to the first dorsal fin, and the results might indicate functional differences between the sexes in this species. Seven morphometric dimensions (interspiracular distance, spiracle length and width, upper and lower tooth band width, pelvic fin length, and length of posterior lobe of pelvic fin) exhibited stability through ontogeny and between sexes and hence are recommended for use in taxonomic studies.

Acknowledgements - A special thank you to fishermen from Santos e Guarujá for donating the specimens used in the study. We also thank people from the Zoological Collection of University of Santa Cecília for help in processing the material in the laboratory, Prof. Dr Otto Bismark Fazzano Gadig for editorial contributions and the São Paulo Research Foundation (FAPESP) for financial support.

\section{References}

Bass AJ. 1973. Analysis and description of variation in the proportional dimensions of scyliorhinid, carcharhinid and sphyrnid sharks. Investigational Report No. 32. Durban: Oceanographic Research Institute.

Bornatowski H, Abilhoa V, Freitas MO. 2006. Sobre a alimentação de Narcine brasiliensis na Baía de Ubatuba-Enseada, São Francisco do Sul, Santa Catarina, Brasil. Estudos de Biologia 28: 57-60.

Braccini JM, Chiaramonte GE. 2002. Intraspecific variation in the external morphology of the sand skate. Journal of Fish Biology 61: 959-972.

Brough J. 1937. On certain secondary sexual characters in the common dogfish (Scyliorhinus canicula). Proceedings of the Zoological Society of London 107: 217-223.

Castillo-Geniz JL, Nishizaki OS, Perez JC. 2007. Morphological variation and sexual dimorphism in the California skate, Raja inornata Jordan and Gilbert, 1881 from the Gulf of California, Mexico. Zootaxa 1545: 1-16.

Clarke KR. 1993. Non-parametric multivariate analyses of changes in community structure. Australian Journal of Ecology 18: 117-143.

Consalvo I, Scacco U, Romanelli M, Vacchi M. 2007. Comparative study on the reproductive biology of Torpedo torpedo (Linnaeus, 1758) and T. marmorata (Risso, 1810) in the central Mediterranean Sea. Scientia Marina 71: 213-222.

Cortes E. 2000. Life history patterns and correlations in sharks. Reviews in Fisheries Science 8: 299-344.

Dean MN, Motta PJ. 2004. Anatomy and functional morphology of the feeding apparatus of the lesser electric ray, Narcine brasiliensis (Elasmobranchii: Batoidea). Journal of Morphology 262: 462-483.

Dean MN, Nietfeld TE, Conklin DS. 2005. Husbandry notes on the lesser electric ray. North American Journal of Aquaculture 67: $58-65$.

de Carvalho MR. 1999. A systematic revision of the electric ray genus Narcine Henle, 1934 (Chondrichthyes: Torpediniformes: Narcinidae) and the higher level phylogenetic relationship of the orders of elasmobranch fishes (Chondrichthyes). PhD thesis, University of New York, USA.

Ellis JR, Shackley SE. 1995. Ontogenic changes and sexual dimorphism in the head, mouth and teeth of the lesser spotted dogfish. Journal of Fish Biology 47: 155-164.

Feduccia A, Slaugher BH. 1974. Sexual dimorphism in skates (Rajidae) and its possible role in differential niche utilization. Evolution 28: 164-168.

Ferreira LC, Vooren CM. 2012. Diet of the lesser electric ray 
Narcine brasiliensis (Olfers, 1831) (Elasmobranchii, Narcinidae) in southern Brazil. Pan-American Journal of Aquatic Sciences 7: 37-44.

Filiz H, Taskavak E. 2006. Sexual dimorphism in the head, mouth, and body morphology of the small spotted catshark, Scyliorhinus canicula (Linnaeus, 1758) (Chondrichthyes: Scyliorhinidae) from Turkey. Acta Adriatica 47: 37-47.

Garrick JAF. 1960. Studies on New Zealand Elasmobranchii. Part XII - The species of Squalus from New Zealand and Australia; and a general account and key to the New Zealand Squaloidea. Transactions of the Royal Society of New Zealand 88: 519-557.

Goitein R, Torres FS, Signorini CE. 1998. Morphological aspects related to feeding of two marine skates Narcine brasiliensis Olfers and Rhinobatos horkelli Müller and Henle. Acta Scientiarum 20: 165-169.

Gomes UL, Signori CN, Gadig OBF, Santos HS. 2010. Guia para Identificação de Tubarões e Raias do Rio de Janeiro. Rio de Janeiro: Technical Books.

Hamlett WC. 2005. Reproductive biology and phylogeny of Chondrichthyes: sharks, batoids and chimaeras. Enfield, New Hampshire: Science Publishers.

Huxley JS. 1932. Problems of relative growth. London: Methuen.

Ishihara H, Ishiyama R. 1985. Two new North Pacific skates (Rajidae) and a revised key to Bathyraja in the area. Japanese Journal of Ichthyology 32: 143-179.

Koehl MAR. 1996. When does morphology matter? Annual Review of Ecology and Systematics 27: 501-542.

Last PR, Stevens JD. 2009. Sharks and rays of Australia. Melbourne: CSIRO Publishing.

Legendre P, Legendre L. 1998. Numerical ecology (2nd English edn). Amsterdam (Netherlands): Elsevier Science BV.

Litvinov FF. 2003. Sexual dimorphism as an index of isolation of West African populations of the catshark Scyliorhinus canicula. Journal of Ichthyology 43: 81-85.

Macesic LJ, Kajiura SM. 2009. Electric organ morphology and function in the lesser electric ray, Narcine brasiliensis. Zoology 112: 442-450.

Macesic LJ, Kajiura SM. 2010. Comparative punting kinematics and pelvic fin musculature of benthic batoids. Journal of Morphology 271: 1219-1228.
Martins RRM, Assunção R, Schwingel PR. 2009. Distribuição e abundância de Narcine brasiliensis (Elasmobranchii, Narcinidae) no litoral norte do estado de Santa Catarina, Brasil. Pan-American Journal of Aquatic Sciences 4: 423-435.

Mathewson R, Mauro A, Amatniek E, Grundfest H. 1958. Morphology of main and accessory electric organs of Narcine brasiliensis (Olfers) and some correlations with their electrophysiological properties. The Biological Bulletin 115: 126-135.

McEachran JD, de Carvalho MR. 2002. Batoids. In: Carpenter K (ed.), The living marine resources of the Western Central Atlantic. FAO Species Identification Guide for Fishery Purposes and American Society of Ichthyologists and Herpetologists, Special Publication 5. Rome: Food and Agriculture Organization. pp 508-589.

Orlov AM, Smirnov AA. 2011. New data on sexual dimorphism and reproductive biology of Alaska skate Bathyraja parmifera from the Northwestern Pacific Ocean. Journal of Ichthyology 51: 590-603.

R Core Team. 2014. R: a language and environment for statistical computing. Vienna: R Foundation for Statistical Computing.

Rosa RS, Furtado M. 2007. Narcine brasiliensis. The IUCN Red List of threatened species. Version 2013.1. Available at www. iucnredlist.org [accessed 2 September 2014].

Rosenblum HG, Long JH, Porter ME. 2011. Sink and swim: kinematic evidence for lifting-body mechanisms in negatively buoyant electric rays Narcine brasiliensis. The Journal of Experimental Biology 214: 2935-2948.

Schaefer JT, Summers AP. 2005. Batoid wing skeletal structure: novel morphologies, mechanical implications, and phylogenetic patterns. Journal of Morphology 264: 298-313.

Vianna GMS, Vooren M. 2009. Distribution and abundance of the lesser electric ray Narcine brasiliensis (Olfers, 1831) (Elasmobranchii: Narcinidae) in southern Brazil in relation to environmental factors. Brazilian Journal of Oceanography 57: 105-112.

Villavicencio-Garayzar CJ. 1993. Observaciones sobre la biología reproductiva de Narcine brasiliensis (Pisces: Narcinidae) en Bahía Almejas B.C.S. México. Revista de Investigación Científica 4: 95-99.

Villavicencio-Garayzar C[J], Bizzarro JJ. 2009. Narcine entemedor. The IUCN Red List of threatened species. Version 2014.2. Available at www.iucnredlist.org [accessed 2 September 2014]. 